\title{
M-Phase Inducer Phosphatase 3
}

National Cancer Institute

\section{Source}

National Cancer Institute. M-Phase Inducer Phosphatase 3. NCI Thesaurus. Code

C104136.

M-phase inducer phosphatase 3 ( $473 \mathrm{aa}, \sim 53 \mathrm{kDa}$ ) is encoded by the human CDC25C

gene. This protein plays a role in cell cycle progression through the G1/S checkpoint. 